\section{Scientific journal}

PHYSICAL AND MATHEMATICAL EDUCATION

Has been issued since 2013.

Науковий журнал

ФІЗИКО-МАТЕМАТИЧНА ОСВІТА

Видається з 2013.
ISSN 2413-158X (online)

ISSN 2413-1571 (print)

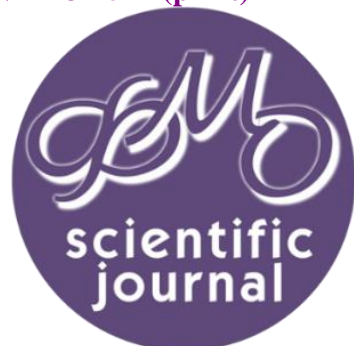

Миленкова Р.В. Неформальна громадянська освіта молоді через партиципативні мистецькі практики. Фізикоматематична освіта. 2021. Випуск 3(29). С. 13-17.

Mylenkova R. Non-formal civic education of youth through participative art practices. Physical and Mathematical Education. 2021. Issue 3(29). P. 13-17.

DOI 10.31110/2413-1571-2021-029-3-002

UDC 37.014

R. Mylenkova

Sumy State University, Ukraine rimma.milenkova@gmail.com

ORCID: 0000-0002-6712-7319

\title{
NON-FORMAL CIVIC EDUCATION OF YOUTH THROUGH PARTICIPATIVE ART PRACTICES
}

\section{ABSTRACT}

Formulation of the problem. Due to the relevance of civic education for young people, in particular high school students, an integrated course of Civic Education was included in the main curriculum. However, there is a problem of lack of a holistic approach, a system of motivation to study the subject, and formal education's limited resources. There is currently a need to intensify civic education through the involvement of the students in practice. The performance of the course and the level of civic education will increase significantly if it is implemented in addition to formal education, in a non-formal one. The article answers the question of how to make the process of training an active citizen more integral and more efficient.

Materials and methods. The experience of Ukrainian public organizations in the implementation of civic education projects through participatory artistic practices is used. The analysis of pedagogical, sociological, and scientific-methodological literature on the education of civic position of youth in the system of formal and non-formal education is applied.

Results. The model of participatory artistic practices is described as a modern tool of civic education and civic action in terms of their multiagent structure, which includes the cooperation of students, educators, artists, school administration, local government representatives, the general community. The methods and approaches to civic education programs are presented. The organizational algorithm of the participatory art practice with elements of civic education is specified.

Conclusions. The existing integrated curriculum for Civic Education, implemented in the tenth grade, needs practical support through the field of non-formal education. This possibility is provided by the algorithms of civic education projects through participatory artistic practices that are implemented in extracurricular time. The introduced cases show the high efficiency of such practices in ensuring the civic competencies of young people. Participation in such practices provides students with the formation of cross-cutting competencies, which are revealed through social activity, social responsibility, tolerance, the ability to advocate their thoughts and positions, the ability to interact both horizontally and vertically.

KEY WORDS: civic education, participatory art practices, non-formal education, civic competencies, activity approach

\section{INTRODUCTION}

Problem statement. Societal demand for civic education faces the problem of the lack of a systematic approach to providing civic education to young people, in particular high school students. The problem is related to scientific and methodological tasks in a search of finding tools of educational influence for the formation of a conscious and active citizen. The relevance of the article lies in the timeliness of the study of formal and non-formal education interaction, to improve civic education efficiency.

Analysis of current research. Actual problems of political culture and civic education in Ukraine are covered in the works of N. Amelchenko, O. Batishcheva, O. Burau, I. Zhadan, I. Ivanyuk, S. Kiselyova, M. Smirnova and others. At the institutional level, the Ministry of Education and Science of Ukraine, non-governmental foundations and organizations represented in Ukraine (the International Renaissance Foundation, the Europe XXI Foundation, the Council for International Studies and Exchanges (IREX), USAID and others) take care of the problem. Despite a large number of studies, such issues as the integrity of the system of formal and non-formal civic education and the increasing interest of young people in the formation of civic competencies remain unresolved.

The purpose of the article is to highlight the methodology of non-formal civic education through participatory artistic practices, which can be effectively applied in extracurricular activities to increase the efficiency of the formal program and provide practical experience of active citizenship.

(C) R. Mylenkova, 2021. 


\section{RESEARCH METHODS}

In the process of the presented exploratory development, methods of analysis of pedagogical, methodical literature and scientific researches were used; generalization of results of domestic and foreign experience was carried out; empirical modelling of multiagent participatory artistic practise with elements of civic education was implemented. This study was conducted as part of exploring the role of non-formal education in the training of active citizens.

\section{RESULTS OF RESEARCH}

The essence of civic education is to form a civic position and common values of freedom, tolerance and non-discrimination at different levels and through different types of education.

Nowadays, when violent border changes, terrorist acts and pandemic quarantine restrictions have been taking place in recent years, calling into question fundamental freedoms, democratic values and respect for the rule of law and human rights. Therefore, the importance of civic education of young people becomes even more relevant in such new socio-economic contexts.

Schooling institutions play an important role in education not only in terms of the formal curriculum but also in terms of life skills. One of the most important missions of educational institutions is to teach how to be active members of a democratic society.

Civic education takes on an institutional function - to create a mature informed electorate and to form an active citizen. Civic Education Course is interdisciplinary, as it integrates numerous skills and competencies that will be applied throughout life in the planes of an individual, a citizen, a specialist.

It is necessary to determine the essence and content of civic education. In democratic countries, the conscious civic activity requires knowledge of history, understanding of the principles and foundations of democracy, motivation to participate in civic, state and democratic processes. At the procedural level, civic involvement in solving public problems, as well as in supporting, strengthening and improving the community and society, is demonstrated.

In general, the directions of such education can be divided into civic education by information content (awareness) and by methods that should contribute to the formation of skills (participatory, critical thinking skills, advocacy, etc.).

In the formal Ukrainian school, an integrated course in civic education was introduced in the 10th grade. "The tasks of civic education, according to the course program, (Hromadyanska osvita, 2018) are to provide purposeful preparation of high school students for functioning in the system of social relations of the multivariate world, globalization, social interaction and active responsible participation in social activities."

Among the expected results of this formal course are the formations of cross-cutting competencies in the blocks "Civil Responsibility", "Environmental Security and Sustainable Development", "Health and Safety", "Entrepreneurship and Financial Literacy".

These themes reflect socially and personally relevant ideas, in particular those that contribute to the realization of the Sustainable Development Goals. Thus, through formal education (given the limit on the number of teaching hours), students acquire mostly informational and content componenti of civic education, which promotes awareness. Also in the formal program, an emphasis is placed on the legal aspects of civil coexistence (Amelchenko. 2017).

However, the methodological basis of the course includes a competency approach as the main one. Undoubtedly, competencies are built through activities, and the basic principles of civic education are the principles of activity and participation. That is why it is necessary to consider extracurricular activities as an underestimated resource for civic education. Extracurricular time, providing more opportunities and fewer restrictions, becomes an effective format, the use of which requires the educator to build a motivational system. Usually, motivational measures become sufficient when students create a sense of involvement, participation, influence, social significance, and so on.

Non the less, at this stage it is also possible to add a formal motivation component - such as facilitating participants with high-level organizational support, certificates and diplomas for participation in projects that will be able to replenish students' CVs in the future, provide important points to cover letters, which significantly increase their marketability.

An informal approach to teaching civic education is manifested in both the form and content of projects. Refined information about electoral processes and the state system is not always of interest to students, because in the upper grades of secondary school they are not yet directly involved in the electoral process and have few tools to influence state and political processes in the country. Therefore, non-formal education, using more pedagogical forms and tools, becomes a practical reinforcement of a formal course in civic education through involvement in volunteer activities, engagement in creative participatory projects. Informal forms are more flexible in the selection of participants in educational groups - they open up more opportunities for inclusion, which realizes the basic values of civic education of young people.

Participatory art practices, known in many countries as Community public art, are an effective tool for civic education to gain experience. The range of such projects is revealed through several directions from performative actions (drama, choreography, concerts and other performances), digital projects (informative, educational, agitation, entertaining), architectural and visual (from the creation of objects to the realization of graffiti, murals, decorations of urban locations, etc.).

Participatory artistic practices (community public art, community-engaged art) are just beginning to be implemented in Ukraine. However, their history proves the effectiveness of the methods. Such practices have become the most common means of civic education in countries where a significant stratification of society has taken place long ago - on the principles of racial, social, political, gender, physical and intellectual differences. Societies that need to implement the principles of understanding and reconciliation are actively using community public art to work with young people. In particular, in the United States, such projects have the institutional support of government agencies and foundations such as the National Endowment for the Arts, Americans for the Arts and others.

By its definition, participatory art (dialogue art, engaging art, collaborative art, collective art) is determined by the fact that the process of creating objects involves a wide community, usually, a group that is united by a certain feature (national, racial, gender, cultural, ideological, etc.). The presence of participatory art on the streets indicates the possibility of free 
expression of groups whose messages have not been verbalized, which means that they have been given a platform for free expression and demonstrate their civic position. In this case, participatory art is not a material object, but the social and educational situation and the event itself.

It should be noted that public art is a means of communication. This means that the artistic expression of the group is not one-sided, it is actualized through feedback from the audience. This response is important not only because it demonstrates public sentiment and can be indicative for the analysis of the stated problem, but also provides material for the interpretation and improvement of further educational projects.

Situations, when participatory artistic practices become an effective tool for influencing society, are defined as (Framing community - a community-engaged art workbook, 2016):

- times of turning points, in a society that needs memorialization;

- the need for self-expression of socially marginalized communities;

- the need to combat stereotypes and stigmas;

- building a dialogue about the differences of social groups;

- establishing public relations:

- return of social spaces;

- collection and transmission of unpublished (not told publicly) stories;

- transmission or creative revision of cultural traditions;

- expansion of social activity and increase active citizenship;

- stimulation or mobilization of social action on a specific situation or problem.

In the context of this article, we speak of participatory artistic practices not as spontaneous creative interventions in public space, but exclusively as a multi-agent model of civic education. By multi-agent structure, we mean fruitful cooperation of educators (curators, teachers, assistants), artists who work with a group of participants, social (or political) consultants, representatives of local governments and artistic experts in the field chosen for the project.

The content load of such practices in educational blocks can be done on such modules.

1. Education for the formation of responsibility for public utterances (whether verbal or visual utterance, intentional or accidental, it leaves an information mark on the canvas of the city and society). Teaching this component includes the development of critical thinking and social analysis, the formation of civic responsibility, prognosis skills and the articulation of long-term goals.

2. Making a civic statement that will be placed in public space (this stage requires immersion on the one hand in the social context of the city, its history, on the other hand - structuring a specific message of a group of students). The experience of project implementation shows the following main messages of inclusive groups: 'Our dreams are the same as yours!' 'We are not chimaeras, we want you to notice us!' 'We live in the same city, it should be equally convenient for us and you'.

3. Work on the ideas' visualization, the transformation of verbal units into symbols (consists of an artistic message, which will then be seen by citizens). This stage becomes the most emotionally motivating one. It includes both individual creativity but also teaches tolerance for the opinions of others, the ability to work in a team as a model of society.

4. The advocacy phase of the project is the most responsible of the participants. Ideas need protection not only on a horizontal level - in front of partners, but also on a vertical level - in front of the administration of educational institutions, the community, local governments. In this way, participants gain experience in negotiating, interacting with the authorities, justifying and defending their projects, resolving conflicts, advocating and promoting results.

5. Participation in the implementation of the artistic part of the practice. This stage corresponds to the principles of activity, civic participation, responsibility, forms the skills of participation in social processes. Authority delegation is also an important skill. At the stage of realization of a mural, a fresco, graffiti, restrictions on participation may appear - either due to low accessibility of space, or due to compliance with safety rules, or due to organizational (such as pandemic) restrictions. The ability to delegate participation to individual participants and to exercise reasonable control over the work of delegates is a necessary competence and experience for participation in further democratic processes.

6. Presentation of the project to the community (residents of the neighborhood, communities interested in the topic or those who are a direct or indirect target audience). This stage provides skills development, like advocacy, public speaking, project lobbying. Young people learn to be agents of social influence, social change, become public figures, interact with the media. The final stage is also important for the analysis of project success, quantitative and qualitative analysis of the processes (gender balance of participants, project inclusiveness, availability of results to the general public, analysis of conflict situations and crisis management, etc.).

Methodologically, participatory practices in civic education through art can be classified as a case study, as they usually focus on solving a certain socially relevant problem, which is holistically considered by the participants. In the process of learning and working, they receive information, tools and experience to solve problems. Such experience is embedded in a case, or algorithm, which can become a model for the further civic activity of young people.

Civic education of young people through participatory artistic practices as a purposeful social activity is realized on the principles of mutual respect, cooperation, inclusiveness, voluntary and selfless contribution.

These principles become most relevant in times of pandemic restrictions when their observance becomes under threat because much of the educational process and creative interaction takes place online and not all aspects of interaction are transparent to the general public.

The multi-agent nature of civic education practices through art is the interdependent interaction of educators, artists, groups of participants and their teachers (and guardians), school management, local governments, the community living where the project is implemented

The role of educators is to organize the process so that at each stage the main task is performed - the formation of skills that are basic for the citizen. 
The role of the artist is to aesthetically reflect the ideas and images proposed by the creative team.

The role of teachers and assistants is to support the ongoing communication process between all process agents. The role of administrative bodies is in the project's administration and control of its legitimacy, documentation, procedural compliance, etc. Thus, only in fruitful interaction do projects become effective from the inside and visible from the outside - for the general public.

The function of providing non-formal civic education can be taken over by educational public organizations. Currently, their activities in the field of education are confirmed by membership in the "Ukrainian Association of Adult Education", methodological support of international educational institutions, and certification of certain educational programs. Non-formal education does not provide comprehensive knowledge or full skills development. However, while not limited to a rigid curriculum, it offers more flexible forms, methods, and approaches that become more student-centered.

\section{DISCUSSION}

Examples of such practices in the city of Sumy are the mural on the wall of the Secondary School №1, the image on the wall of a Specialized School for Children who Need Correction of Physical and Mental Condition, the project "City of Content", the fresco "City of Flowers" in the city centre, fresco "Chimeras", made by a group of people with disabilities.

The "City of Content" project (Misto Zmistu, 2019) was the most measurable for interpretation, as several questionnaires and surveys were conducted during the registration and selection of participants.

The results showed a gender imbalance of participants with a predominance of women (65\%), and low inclusion (5\%), however, a high level of group participation - not individual participation, but with family, class, teachers, group, etc. (74\%). In general, the results correspond to the statistics of involvement in the social life of the people of Ukraine, although they leave room for influence in the selection of participants.

The subject content was also analyzed in the presented works. Most of them were patriotic at the national level - $65 \%$, historical about the city and its cultural aspects - 18\%, identifying (who declare their membership in a group or organization) $10 \%$, and only $7 \%$ can be defined as those who have an entertaining format. These data indicate a high level of social involvement, patriotism and socio-political awareness of the participants because in preparation for the project they study the contexts of social coexistence and independently determine the points of influence on it.

However, the algorithms are not rigid and similar to all the case studies.

Working in inclusive participatory art projects requires the specifics of interaction, as well as the presence of another agent - a teacher-assistant of a child with disabilities. Participants are involved in most of these projects only at the stage of discussion and sketching, while the implementation of the mural is carried out by experts based on the ideas and recommendations of the participants. Messages from such projects can be presented following the example of the inclusive Chimera project (supported by the International 'Renaissance' Foundation, 2021): 'You don't see us', 'We exist', 'We are different, but we feel the same', 'See us, hear us', 'We are not chimaeras, we are real people'. Such statements to society through artistic practices can also be a valuable contribution to community development, building accessible locations, changing public attitudes towards people with disabilities. Thus, similar projects for inclusive groups have two directions. The first is the civic education of the participants themselves. The second is to help society in defragmenting social ties, removing people with disabilities from social reservations.

Demonstrably, the implementation of participatory projects in civic education requires professional training of educators and other agents of influence and organization, adherence to the principle of participation and activity, building a communication system at the horizontal and vertical levels.

\section{CONCLUSIONS AND PROSPECTS FOR A FURTHER RESEARCH}

Summarizing the above material, it can be noted that non-formal civic education is a necessary element of citizen training. The importance of non-formal education is that it increases motivation for civic education, activities and further social participation. The community benefits with a wide impact - new social ties are built through projects and social capital is increased.

Thus, participatory artistic practices with elements of civic activity are an effective tool for civic action and the formation of civic competencies.

However, the question of measuring such competencies and analyzing their components is still urgent. The prospects for further research are seen in the development of a system for measuring the civic competencies of young people.

\section{References}

1. Amelchenko, N.(2017). Analiz suchasnyh navchalnyh program schodo hromadyanskoyi osvity ta politychnoyi sistemy Ukrayiny. Modern curriculum of civic and political education in Ukraine snalysis. Retrieved from: https://parlament.org.ua/wp-content/uploads/2017/09/Analiz-Amelchenko_red.pdf.

2. Billig, S., Root, S., Jesse, D. (2005). The impact of participation in service-learning on high school students' civic engagement. Medford, MA: The Center for Information and Research on Civic Learning and Engagement.

3. Framing community - a community-engaged art workbook. Ontario Arts Council, 2016, 62 p. Retrieved from https://www.arts.on.ca/oac/media/oac/Publications/Framing-Community-A-Community-Engaged-Art-Workbook.pdf.

4. Galston, W. A. (2007) Civic Knowledge, Civic Education, and Civic Engagement: A Summary of Recent Research _International Journal of Public Administration, pp. 623-642.

5. Just Exactly What Is Civics Education? Education Commission of the States, 2021. Retrieved from https://ednote.ecs.org/justexactly-what-is-civic-education/.

6. Hromadyanska osvita (integrated course). Curriculum. Ministry of education and science of Ukraine. 2018. Retrieved from: https://mon.gov.ua/ua/osvita/zagalna-serednya-osvita/navchalni-programi/navchalni-programi-dlya-10-11-klasiv 
7. Rupers, B. (2018). High School Visual Arts and Student Civic Engagement Benjamin Rupers. Dominican Scholar. 5-18, 61 p. Retrieved from https://scholar.dominican.edu/cgi/viewcontent.cgi?article=1327\&context=masters-theses

8. Torney-Purta, J. (2002). The school's role in developing civic engagement: A study of adolescents in twenty-eight countries. Applied Developmental Science, 6, pp. 203-212.

9. What is Education for Democratic Citizenship and Human Rights? Council of Europe. Retrieved from: http://www.coe.int/t/dg4/education/edc/1_What_is_EDC_HRE/What_\%20is_EDC_en.asp.

\section{НЕФОРМАЛЬНА ГРОМАДЯНСЬКА ОСВІТА МОЛОДІ ЧЕРЕЗ ПАРТИЦИПАТИВНІ МИСТЕЦЬКІ ПРАКТИКИ}

\section{Р.В. Миленкова}

Анотація.

Сумський державний університет, Україна

Постановка проблеми. У зв'язку з актуальністю громадянської освіти молоді, зокрема учнів старших класів, до основної навчальноі програми було внесено інтегрований курс з громадянської освіти. Проте, виникає проблема відсутності цілісного підходу, системи мотивації до вивчення предмету, обмеженості ресурсів формальної освіти. Наразі існує потреба в інтенсифікації громадянської освіти через залучення до практичної діяльності. Ефективність курсу та рівня громадянської освіти значно підвищиться, якщо вона буде реалізуватись крім сфери формальної освіти, також у неформальній. Стаття відповідає на питання, як зробити процес підготовки активного громадянина цілісним і більш ерективним.

Матеріали і методи. Використано досвід українських громадських організацій у реалізації проектів з громадянської освіти через партиципативні мистецькі практики. Застосовано аналіз педагогічної, соціологічної та науково-методологічної літератури щодо виховання громадянської позиції молоді в системі формальної та неформальної освіти.

Результати. Представлено модель партиципативних художніх практик як сучасного інструменту громадянської освіти $і$ громадянської дії, які реалізуються за умов їх мультиагентної структури, що включає співпрацю тих, хто навчається, едукаторів, художників, адміністрацію закладу освіти, представників органів місцевого самоврядування, широку громаду. Описано методи і підходи до реалізації заходів в межах програми з громадянської освіти. Окреслено організаційний алгоритм партиципативних мистецьких практик з елементами громадянської освіти.

Висновки. Існуюча інтегрована навчальна програма з громадянської освіти, впроваджена в десятому класі, потребує практичного підкріплення через среру неформальної освіти. Таку можливість надають алгоритми проектів з громадянської освіти через партиципативні художні практики, які реалізуються у позанавчальний час. Упроваджені до практики кейси показують високу ефективність таких практик у забезпеченні громадянських компетентностей молоді. При застосуванні комплексного підходу до громадянської освіти через об'єднання формальної і неформальної освітніх систем, формування активного громадянина здійснюється більш ефективно і забезпечує на тільки інформаційну складову, але й діяльнісну. Участь у таких практиках забезпечує учням формування наскрізних компетентностей, які розкриваються через соціальну активність, сочіальну відповідальність, толерантність, здатність до адвокації власних думок і позицій, вміння взаємодіяти як на горизонтальному рівні, так і на вертикально-ієрархічному.

Ключові слова: громадянська освіта, партиципативні мистецькі практики, неформальна освіта, громадянські компетентності, діяльнісний підхід. 